\title{
Editorial note to the inaugural issue
}

\author{
Nikolaos St. Skourtos
}

Published online: 7 February 2010

(C) Aegean Institute of the Law of the Sea and Maritime Law 2010

This is the inaugural issue of the international law review of the Aegean Institute of the Law of the Sea and Maritime Law, aiming to offer the international scholarly community a new forum for the presentation, analysis, discussion and assessment of recent developments and research results in the fields of both the law of the sea and maritime law.

These two legal disciplines have not been brought together in one publication simply for the sake of innovation, nor merely for the purpose of tailoring the review to the fields of activity of the Institute. The idea is to emphasize that they are interrelated and form part of the legal order of the marine space, considered as a unit despite its technical division into separate branches or levels of application: international, regional or national. Indeed, if the sea is to continue to unite people, this goal can only be accomplished by means of a stable legal order for the marine space characterized by homogeneity or at least by continuity between its constituent branches.

This is of course only one side of the coin, for it is equally important that this legal order be a good one, that is, a legal order which is inspired by common interests rather than by selfish ones, thus deserving respect and observance by all for the benefit of all.

A stable, homogenous, and good legal order for the governance of the marine space is therefore the goal the Aegean Review aims to serve. In this respect, the Review draws upon a tradition which has its origins in the history of the island of Rhodes, where the Aegean Institute is located. It is well known that around the second century B.C. a body of rules connected with the island of Rhodes and regulating marine trade won recognition all over the Eastern Mediterranean because of its quality. Of course, this Rhodian law, or Lex Rhodia as it has come to be known, could not have been produced through parthenogenesis, as a great number of rules of customary character already existed in the area for centuries, since the

N. St. Skourtos $(\bowtie)$

Aegean Institute of the Law of the Sea and Maritime Law, Rhodes, Greece

e-mail: aeginst@rhodes.aegean.gr 
period of Phoenician supremacy at least, regulating a lively seaborne trade. It was, however, the skill of the Rhodian lawmakers, combined with their love for eunomia (the rule of good law) which led them-we assume, as very little is known even about the content, let alone the legal form of this law-to arrive at some kind of compilation of those rules and presumably to their 'progressive development'. Thus, the Rhodians placed a law at the service of all the peoples of the Mediterranean which proved to be workable for centuries. The words of the Roman emperor Antoninus Pius, spoken on the occasion of a decision on a case put before him, provide evidence of the quality of this law and the general recognition it enjoyed. These words, handed down to posterity in a rescriptum contained in the Digest of Justinian (DIG. 14.2.9), which the Aegean Institute has placed in its logo, can be literally translated as follows: "I am the master of the world but custom is the master of the sea. Let this issue be judged according to the maritime law of the Rhodians in matters where no law of ours states to the contrary".

However, the wish to contribute to the endeavours of the international academia towards the achievement of a good law for the marine space or the inspiration drawn from the significant contribution of the ancient Rhodians in this field would not be sufficient for the Aegean Institute to make the decision to launch an international law review. The decisive factor has been our belief that the Institute is in a position to meet the challenges of such an undertaking due to the support of a great number of colleagues and friends within the international academic community, whom the Institute has had the privilege to welcome during the sixteen years of its existence. This is exemplified by the Rhodes Academy for Oceans Law and Policy, organized since 1996 in cooperation with the Center for Oceans Law and Policy of the University of Virginia (USA), the Max Planck Institute for Comparative Public Law and International Law, Heidelberg (Germany), the Netherlands Institute for the Law of the Sea, Utrecht (The Netherlands) and the Law of the Sea Institute of Iceland, Reykjavik (Iceland). Indeed, during this period more than five hundred scholars of eighty different nationalities have participated in the Rhodes Academy sessions, during which more than eighty distinguished members of the international scholarly community have lectured on a wide variety of subjects relating to the legal aspects of the use of marine space, including its physical environment and its protection. In addition, during the past fifteen years more than one hundred and sixty scholars of the Aegean Institute, originating from the Balkans, the Black Sea and the Mediterranean, have participated in the Summer Program with special emphasis on maritime law, which is organized in Rhodes by Tulane University of New Orleans and sponsored by the Institute.

This support has already been received, as seen not only in the composition of the Review's editorial board, but also in the contributors to this first issue: Thomas Mensah, first President of the ITLOS and member of the faculty of Rhodes Academy since its early days; ICJ Judge Bernardo Sepúlveda-Amor, keynote speaker at the Academy in 2009; Professors Tullio Scovazzi and Jose Juste-Ruiz as well as Dr. Ronan Long who taught at the Academy, the latter having also been a student there; Ph.D. candidates Lowell Bautista and Ioannis Konstantinidis who have been students of the Academy and Ms. Zuzanna Peplowska, Ph.D. candidate and scholar of the Aegean Institute to the Tulane program. However, the Review also welcomes 
contributions from all members of the international academic community as well as practitioners with no previous connection to the Aegean Institute, as seen in the contributions of Dr. Miguel García García-Revillo, Xavier Vázquez, Sara Monteiro, Yiannis Timagenis and Stavros Stavroulakis in this first issue, which we hope will be the first of many productive issues to follow.

Dr. jur. Nikolaos St. Skourtos

Director of the Aegean Institute of the Law of the Sea and Maritime Law Managing Editor 